\title{
Analysis and Research on Countermeasures of Small and Micro Enterprises' Financing Predicament under China's New Environment
}

\author{
Lingzhi Deng ${ }^{1, a^{*}}$ and Cheng Wang ${ }^{2, b}$ \\ ${ }^{1}$ School of Management, Wuhan University of Technology, 430070, Wuhan, P.R.China \\ ${ }^{2}$ Institute of Electrical and Information Engineering, Hunan University, 410082, Changsha, P.R. \\ China \\ a15527929909@163.com, bdarrenwangcheng@163.com
}

Keywords: China's new normal; Small and micro businesses; Financing predicament; Countermeasures.

\begin{abstract}
The small and micro businesses are a dispensable and effective strength to promote economic growth under China's new normal, while difficulties in financing have become the bottleneck of their development. This paper is based on the current financing status of small and micro enterprises, combining with a series of financing policy for the small and microenterprises. Also the paper explore the small and micro businesses' financing present situation, pointing out that there are opportunities and challenges for the small and micro enterprises' financing under China's new normal. At the end of the paper, there are corresponding countermeasures put forward which are based on the characteristics of China's new normal from the levels of small and micro businesses, financial institutions and the government.
\end{abstract}

\section{Introduction}

Micro enterprises, family workshops enterprises, privately or individually-owned businesses are collectively known as small and micro businesses, which are the basic cell of our economy and has an irreplaceable role in the steady growth of economy. Firstly, there are a large number of small and micro enterprises. According to the "National Small And Micro Enterprise Development Report" issued by State Administration for Industry and Commerce in 2014 [1], by the end of 2013, the amount of the small and micro enterprises is about 1.7 million, If 44.36 million privately or individually-owned businesses are also regarded as micro-enterprises included in the statistics, then the proportion would reach to $94.15 \%$. Although the tax contribution of individual small and micro enterprise is low, due to the huge number of small and micro enterprises, they still can contribute a large portion of the total tax revenue to the country. Secondly, small and micro enterprises solve the employment problem of a considerable part of our country. Workers in small and micro enterprises are mostly low educational attainment; they are urban residents or city workers whose household income is not high. If small and micro enterprises are facing difficulties or the risk of bankruptcy in their operation, these people will face unemployment and predicament of no source of income.

\section{Analysis on Small and Micro Enterprises' Financial Current Situation and Dilemma}

According to the "Small and micro businesses debt report" lately jointly issued by the by the third party payment agencies named china PNR and Southwestern University of Finance and Economics [2], there are only 46.2 can get loans in each of the 100 small and micro businesses which are demand for bank credit. 80 percent of them rely on private financing. "Financing difficulties" is widespread in the development of small and micro enterprises. Since 2014, government has introduced a series of policy initiatives to promote sustainable development of small and micro enterprises [3]. Especially in the first half of 2015, preferential tax policies are frequently introduced by our government in order to encourage small and micro enterprise development, the scope of preferential policies of tax payer are more than $80 \%$. In terms of corporate income tax policy, the government has extended the scope of the preferential half income tax policies for three 
times. In terms of income tax, the PRC EIT Law provides that the enterprise which annual taxable income is less than 200,000 can enjoy preferential tax rate of 10\%[4].In terms of value added tax, enterprises that monthly sales revenue are 30,000 yuan (below) or quarterly sales income in 90,000 yuan (below) can enjoy duty-free concession. (Refer with: Table 1)

Table 1 Financial Policies Support for small and micro enterprises from 2014-2015

\begin{tabular}{|l|l|}
\hline Data & \multicolumn{1}{c|}{ Policy } \\
\hline Apr. 2014 & $\begin{array}{l}\text { Executive meeting of the State Council decided to extend the tax cut for small } \\
\text { and micro enterprises, to further raise the upper limit of implementation scope of } \\
\text { small and micro enterprises preferential policies. }\end{array}$ \\
\hline May 2014 & $\begin{array}{l}\text { The State Council clearly proposed measures to reduce and regulate the charges } \\
\text { involved in Small and micro businesses, and to reduce the burden Small and micro } \\
\text { businesses. }\end{array}$ \\
\hline Sept. 2014 & $\begin{array}{l}\text { Executive meeting of the State Council discussed the creativity development of } \\
\text { small and micro enterprises, proposed some measures to further strengthen the } \\
\text { sustainable development of small and micro enterprises and enhance their } \\
\text { innovation capability. }\end{array}$ \\
\hline Nov. 2014 & $\begin{array}{l}\text { The State Council issued the "Opinions on supporting the healthy development } \\
\text { of } \\
\text { development of the small and micro enterprises from preferential tax policies, } \\
\text { financial guarantee support, entrepreneurial base construction, information service } \\
\text { etc., and pointed out the direction of promoting small and micro enterprises' } \\
\text { sustainable development. }\end{array}$ \\
\hline Mar. 2015 & $\begin{array}{l}\text { The Ministry of Finance and the State Administration of Taxation jointly issued } \\
\text { the "Notices on the preferential policies for the income tax of small and micro } \\
\text { enterprises" to halve the income tax of those small and micro enterprises who meet } \\
\text { the conditions. }\end{array}$ \\
\hline $\begin{array}{l}\text { Approved by the State Council, the Ministry of Finance, and the State } \\
\text { Administration of Taxation jointly issued the" Notice on the exemption of } \\
\text { government funds for small and micro enterprises" } \\
\text { The State Council issued the "Opinions on several measures of promoting mass } \\
\text { entrepreneurship and innovation" }\end{array}$ \\
$\begin{array}{l}\text { The People's Bank of China announced that cutting the reserve requirement } \\
\text { hikes of commercial banks which "Three Rural" or small and micro loan reached to } \\
\text { certain standard by 0.5\% from 28 June. }\end{array}$ \\
\hline Jun. 2015. 2015
\end{tabular}

Thus, it can be seen that the government's emphasis on small and micro enterprises' development is relatively high. This objectively requires our society further to build the financing path to adapt to the sustainable development of small and micro enterprises. Overall, the current situation of small and micro enterprises financing can be summed up in three aspects.

The Degree of Eternal Integration Is Continued to Increase, the Small and Micro Enterprises Are Facing More Complex Internal and External Financing Environment. With the deepening of the impact of the international financial crisis, the government's regulatory requirements for financial institutions, including commercial banks, shadow banking and other financial institutions, are increasingly stringent. In 2010, the new "Basel agreement III" was introduced, which put forward higher requirements to the risk management of commercial banks [5].

From the current development of China's commercial banks, the risk based on off-balance sheet activities (OBSA) is small [5]. But the bank systemic risk arising from convergence of financial credit business also becomes an important part of strengthening capital and liquidity regulation. In addition, the private financing model which lack of a reasonable guide and standardize also has the 
potential to cause greater financial risk. This will have an impact on some of the small and medium financial institutions committed to provide financing services to small and micro enterprises.

Since 2014, China's economy has increased the degree of opening to the outside world. Under the new normal, the development of the national economy is more complex. How to grasp the financing laws under the development of free trade, and how to be initiative to change and seek the meeting point of the market have become the key for the small and micro enterprises. However, the current construction of small micro enterprises' financing system is relatively lagging behind.

The Balance of Supply and Demand for Financing Is Low; the Individual Financial Support Is Weak. In the background of sluggish development of the financial market development, financial services have difficult to meet the financing needs of a large number of small and micro enterprises. There are higher costs for small and micro enterprises to obtain financing support. The bank lending rates for small and micro enterprises generally higher than the bank's benchmark interest rate, floating up to about 50\% [6]. At the same time, their bargaining power is relatively low, Banks provide additional funds in the process of loan, such as purchase of financing goods or gold products, bear the guarantee fee or assessment fees, which would directly increase the cost of small and micro enterprises financing.

At the same time, China's financial services system is still in development stage, large and Medium-sized enterprises has been given larger support on the financial services, accounting for more than $80 \%$ [7]. Small and micro enterprises have greater difficulties in accessing to financial support. In addition, China pays more attention to the quality of economic development under the new normal; there are new requirements for enterprise innovation, sustainability. Although the small and micro enterprises are of high flexibility and innovational merge, their sustainability is relatively low; it is difficult for them to form a tacit understanding with the market in a timely manner.

In addition, State-owned commercial banks' loan approval process is very strict. Applying for a loan usually takes a month or even six months or so. However, the small micro-enterprise s' demand for capital is characterized by a small number and time urgency, so contradictory follows. A survey pointed out that most companies take the initiative to give up the loan because of the higher cost of time, even if some companies get loans, they still had lost to seize market opportunities. Thus, the complexity of loan approval process, high cost of time result in the loans difficult for small and micro enterprises.

Financing Integrity Is Not High; The Contradiction Is More Prominent between Financing Efficiency and Financing Needs. Small and micro enterprises' own limited capacity also affects its financing [8]. On the one hand, their financial management is relatively less normative. The lack of scientific and efficient financial management method and management system makes their overall credit rating is comparatively low. Thus the efficiency of direct financing for these enterprises is relatively low. The problem of low capital management efficiency, lack of financial system, the simplified financial information, the low credibility of the financial statements, cause the bank unable to carry on the credit examination through the report forms to the enterprise. At the same time, China has not yet formed a corresponding credit evaluation mechanism small and micro enterprises, the cost of small and micro enterprises to break the promise is not high.

On the other hand, small and micro enterprises' limited asset size led to weak security capabilities; Compared to large and medium-sized enterprises, the main problems of small and micro enterprises are small scale, poor operational capacity, low profit margins, and lack of self-accumulation and so on. They have less stable operating conditions, and lack of adequate and effective guaranty.

\section{Research on Small and Micro Enterprises' Financing Countermeasures under New Environment}

Today, China's economic development has entered a stage of "new normal", the so-called "new" that is different from the past which development is traditional and extensive; the so-called "normal", referring to that such a state of development will remain stable for a longer period time. 
This economic background for small and micro enterprises is not only a rare opportunity, but also a great challenge [9]. Small and micro businesses serve as an important force to promote economic transformation and upgrading, their financing difficulties is caused by many factors, which cannot merely be solved by market mechanisms and requires small and micro enterprises, financial institutions and the government together to resolve.

Enhance the Financing Capacity of Small and Micro Enterprises Themselves. Under the new normal, enterprise should pay more attention to the quality of development. This objectively requires small and micro enterprises to actively adapt to the new economic trend. Firstly, establishing credit evaluation platform combined with the current situation of small and micro enterprises, which can make small and micro enterprises to actively establish a sense of integrity. Secondly, guide the small and micro enterprises to establish a sound financial management system, so that they can meet the requirements for standardized financial information during the financing process. Thirdly, guide them to actively carry out industrial restructuring under the policy guidance, so as to enhance the industrial clustering ability and comprehensive financing capacity. Therefore, enhancing the comprehensive competitiveness, complying with the new normal, is the key to enhance their ability to finance enterprises.

Improve the Management and Monitor Functions of Government Departments. Under the new normal, government enacted a series of monetary policy which targeted small and micro enterprises, such as tax incentives and discount loan. Accordingly, how to promote these financial policies to be efficiently implemented has become the key to help small and micro enterprises for sustainable development.

First of all, the problem in financing of information asymmetry should be solved. Adverse selection and moral hazard problems in information asymmetry will lead to higher cost of information and transaction costs, which will ultimately lead to the problem of financing dilemma. To solve this problem, it requires the government to promote information transparency and the establishment of credit evaluation system between supply and demand sides of the small micro-enterprise. Allowing financial institutions to has detailed knowledge of the small and micro enterprises' credit rating, so as to standardize the lending rate.

Furthermore, in order to solve the problem of less effective financing channels, government should gradually reduce the threshold of the capital market, and encourage the emerging of more small and micro financial services, such as small loan companies, security companies, financial leasing companies, so as to broaden the financing channels.

Vigorously Promote Financial Institutions' Services Targeted at Small and Micro Business. Firstly, the "Small micro-enterprise debt Survey Report" shows that 36.3\% of small and micro businesses think the process of application is very troublesome, $10.1 \%$ of them do not know how to apply[10]. Both of the two points are non-market factors. This reflects that the service level of financial institutions should be improved. Financial institutions should focus on increasing the human and financial resources of small and micro enterprises' loan services, simplifying examination and approval process, and improving the efficiency and pass rate of small and micro enterprises' loan. Secondly, under the guidance of national policy, financial institutions need constantly innovative services and put the small and micro enterprises into the daily management system.

Besides, the financial institute should design risk management tool specifically for small and micro businesses to manage their loan. Due to the uncertainty of their operating status of small and micro enterprises, financial institutions at this stage do face a larger risk of bad debts, when provide the small and micro enterprise with loans. But the financial institutions can never ignore the growing financing needs from these enterprises. Instead, financial institutions should design risk management tools designed to manage small and micro business loans, which adapt the characteristics and development of small and micro enterprises.so as to set up their own "double insurance". 


\section{Conclusion}

In the background of the "new normal", small and micro enterprises have gradually become the main force in the process of industrial enrichment, product differentiation and business model diversity. And it needs the joint efforts of corporations, financial institutions and the government's to resolve the financing plight of small and micro enterprises. Such efforts can not only makes small and micro businesses expand the investment of management and technical R\&D, it also has a very significant significance for steady growth, promoting reform, structural adjustment and benefiting people's livelihood.

\section{References}

[1] Y.M. Zhao, H.J.Wei: Economic Review, (2012) No.11, p.56. [In Chinese].

[2] X.Z. Wen, Z.M.Tan and X.Li: Southwest Finance, (2015) No.11, p.68. [In Chinese].

[3] Y. Yan: Business, (2015) No.01, p.01. [In Chinese].

[4] C. Liu: Money China, (2015) No.10, p.44. [In Chinese].

[5] K. Li: Communication of Finance and Accounting, (2014) No.02, p.17. [In Chinese].

[6] J. Zhang: Economic Review, (2014) No.06, p.71. [In Chinese].

[7] L. Liu, J.Tan: China State Finance, (2014) No.15, p.67. [In Chinese].

[8] W. Hu: Journal of Hebei University (Philosophy and Social Science), (2014) No.05, p.128.[In Chinese].

[9] Q.R. Li, S. Liu: Journal of Hubei University (Philosophy and Social Science), (2012) No.06, p.115.[In Chinese].

[10]L. Long, Q. Li: China State Finance, (2012) No.24, p.63. [In Chinese]. 